\title{
Principles of Polish Environment Protection Law
}

\author{
http://dx.doi.org/10.12775/PYEL.2012.006
}

\section{The concept of principles of law}

Over the years various views and opinions evolved on the role of principles of law, their influence on establishing regulations of law, application of law and its interpretation. Though numerous acts feature the notion of principles of law, it seems pretty tough to determine what they are in fact. One of the opinions of Robert Alexy ${ }^{1}$ states that among norms of proceeding rules and principles can be distinguished, where rules are optimisation norms which can be fulfilled to some, possibly the greatest available extent. Moreover, when two principles collide, supporting one of them does not necessary mean that the other ceased to be binding and in force (which remains true for rules $)^{2}$. Principles of law shall express values not included in rules, which

* Nicolaus Copernicus University in Toruń.

1 Robert Alexy (born 1945), a German lawyer and philosopher.

2 T. Gizbert-Studnicki, Zasady i reguty prawne, „Państwo i Prawo” 1988, No. 3, p. 18 and 20 . 
are to be used by application of law. So principles are rather not explicit, but on the contrary - they are to make the law system solid and serve as an aid in a just interpretation of law regulations.

Principles of law may be divided into these which refer to the entire Polish legal system (i.e. lex retro non agit or lex specialis derogat legi generali) and those significant only to certain sections or divisions of the law system. There is a heated argument in the literature on how to understand the Polish environmental protection law. One say that is shall be recognised as an independent division of law. The others are convinced that it is only a bunch of acts and regulations focused on a common theme which is protection of the environment. The proper determination here is quite significant, as an independent division of law shall have its own general principles. Hence, if it can be assumed that the Polish environment protection law is nothing more than a gathering of acts on protection of water, air, climate and other environmental factors which do not constitute an independent division of law, then it shall be considered if we can think about general principles of such an assembly of legal acts.

Another issue is binding force of principles of law. There are opinions that the Environmental Protection Act of 2001 (further referred to as the EPA) shall be recognised as a 'super-act', whereas other acts which refer to protection of the environment (i.e. the Act on Waste, the Hunting Law) are its subsidiaries, specialised in certain areas of environmental protection. If such an approach was accepted, the topic of this study would be only the principles named in the EPA, however they would apply to all acts referring to the Polish environmental protection law. According to the other view, it cannot be regarded as an independent division of law, hence there are no principles of a certain assembly of environmental law regulations, but only principles of one act of law, of a narrow scope of application ${ }^{3}$.

Regardless of the accepted point of view, it cannot be denied that there are certain rules governing the Polish environmental protection law, which can be clearly seen in the title of the EPA: Section II named ,Definitions and general principles'. Accordingly, the attention here shall be drawn to the problem of distinguishing principles of law. If we assume that a certain division of law is ruled by some principles, it should be considered how they can be distinguished. There are numerous concepts on how to divide 
principles of the environmental protection law ${ }^{4}$. As an example, in J. Boć opinion 'a general principle shall be a legal principle, not an idea [...] or [...] a postulate' and shall have an universal application. He also distinguishes the following principles in the EPA: a principle of usage of the environment, principle of integrity, prevention and precautionary principle, 'polluter pays' principle, planning principle, right to information on environment principle, principle of society's right to participation in proceedings on decisions referring to environment protection, obligation of usage of the reference methodology principle 5 . Some authors, however, also include principles which do not originate from the EPA, such as sustainable development principle (which in Poland originates from the Constitution), others do not recognise some principles as of a general character ${ }^{6}$.

This study will cover both principles originating from the EPA, as well as others which undoubtedly refer to environmental protection but originate from other sources of law.

\section{Constitutional principles of environmental protection law}

General principles of environmental protection law have been included not only in the EPA but also in the Constitution of Poland ${ }^{7}$. This fundamental legal act also features ratified international agreements as the sources of law in Poland, hence all such international treaties and EU regulations build up the legal regime in Poland. Three articles of the Constitution refer to protection of the environment:

Art. 5. The Republic of Poland [...] provides environmental protection according to the sustainable development principle.

4 B. Rakoczy, Zasady prawa ochrony środowiska [in:] Leksykon ochrony środowiska edited by J. Ciechanowicz-McLean, Warszawa 2009, p. 403-404.

5 J. Boć, Zasady ogólne w ustawie prawo ochrony środowiska, "Acta Universitatis Wratislawiensis. Przegląd Prawa i Administracji”, 2002, p. 73.

6 See: B. Bomanowski, Zasady ogólne prawa ochrony środowiska. Porównanie ujęcia polskiego i rosyjskiego [in:] Dekada harmonizacji w prawie ochrony środowiska edited by M. Rudnicki, A. Haładyj, K. Sobieraj, Lublin 2011, p. 129-130.

7 The Constitution of the Republic of Poland of 2 April 1997 (Journal of Laws, No. 78, item 483 with amendments). 
Art. 74 . 1. Public authorities run policy which secures ecological safety for the contemporary and future generations. 2. Protection of the environment is the obligation of public authorities. 3. Anyone has the right to information on the environment. 4. Public authorities support citizens' activities aimed at protection and improvement of the environment.

Art. 86. Everyone is obliged to care for the environment and is responsible for its deterioration. Rules of this responsibility are set out in a separate act.

The sustainable development principle (article 5), the right to information on the environment principle (article 74 section 3 ) and the principles of responsibility for damage (article 86) will be described below. The principle featured in article 74 of the Constitution of Poland which can be seen as a basis for running ecological safety and environment protection policy, hence addressed to public authorities and determining their scope of activity. For that reason it was only briefly mentioned.

The essence of sustainable development is aspiration for a harmonious relation between a constant social and economic growth and protection of the environment. Although this principle originates from the Constitution of Poland, it has been defined in article 3 item 50 of the EPA as socialeconomic development, which integrates political, economic and social actions with preservation of natural balance and durability of essential natural processes with the aim of ensuring the possibility of satisfying basic needs of certain societies or citizens of the contemporary generation and future generations ${ }^{8}$.

Apart from business entities and citizens, main subjects responsible for the execution of sustainable development principle are the state and selfgovernment agencies. Among many actions implemented with the aim of reaching such a development model there is a strategy developed in 2000 called Poland 2025 - Long-term strategy of a Constant and Sustainable

8 The preamble of the preceding act of 31 January 1980 on protection and shaping of the environment (Journal of Laws of 1994, No. 49, item 196 as amended) described the sustained development principle as aspiration for i.e. reasonable usage of non-renewable resources and replacing them with their substitutes, limitation of nuisance for the environment and not crossing the limits sets by its resistance, securing ecological safety for citizens. The art. 3 item 3a of the preceding act defined the sustainable development almost identical comparing to art. 3 item 50 of the EPA As B. Rakoczy remarked it, this principle shall be recognised with a flexible approach as the world and the environment change, therefore it shall not be defined in any legal act. See: B. Rakoczy, Zasada zrównoważonego rozwoju [in:] Leksykon ochrony środowiska edited by J. Ciechanowicz-McLean, Warszawa 2009, p. 401. 
Development. This document elaborated by the Governmental Centre for Strategic Studies in cooperation with the Ministry of the Environment comprises the government strategy pointing directions of economic development in the context of environmental protection. Main objectives of the environmental protection policy are set out in the II Ecological Policy of the State'.

The anthropocentric character of the sustainable development principle shall be emphasised, since its aim should not be understood as environmental protection as such, but preservation of the environment for requirements of the contemporary and future generations ${ }^{10}$. Hence, this principle refers not only to law sphere, but also has economic and political science references ${ }^{11}$. Analysing social dimension, the subject of the development shall be a human having the right to live 'according to nature'. In economic dimension development will influence e.g. technical progress, spread of entrepreneurship or increase effectiveness of resources use. In ecological dimension development relates to responsibility of any person or institution for making any changes to the environment ${ }^{12}$. The idea here is to harmoniously blend the national natural and cultural heritage with civilization and social progress ${ }^{13}$.

Last but not least, the execution of the sustainable development principle consists in minimizing actions harmful for the environment, nature-friendly managing, change of production and consumption model and restoring the environment in case of its deterioration ${ }^{14}$. Application of this principle will succeed if it is applied commonly by the states, but also on the everyday level

\footnotetext{
html.

9 www.mos.gov.p1/artyku1/329_polityka_ekologiczna/339_II_polityka_ekologiczna.

10 Z. Bukowski, Zrównoważony rozwój w systemie prawa, Toruń 2009, p. 452.

11 A. Papuziński, Filozoficzny wymiar zasady zrównoważonego rozwoju. Zarys problemu [in:] Prawo i polityka w ochronie środowiska. Studia z okazji 40-lecia pracy naukowej Jerzego Sommera edited by H. Lisicka, Wrocław 2006, p. 259.

12 J. Ciechanowicz-McLean, Zasada zrównoważonego rozwoju w europejskim i polskim prawie ochrony środowiska [in:] Unia Europejska w dobie reform. Konwent Europejski - Traktat Konstytucyjny - Biata Ksiega w sprawie rzqdzenia Europq edited by C. Mik, Toruń 2004, p. 465.

13 D. Pyć, Zasady prawa ochrony środowiska [in:] Ochrona środowiska edited by Z. Brodecki, Warszawa 2005, p. 368.

14 J. Ciechanowicz-McLean, Zasada zrównoważonego..., p. 470.
} 
of human cooperation and solidarity ${ }^{15}$. It can be even said that sustainable development is a global matter ${ }^{16}$.

\section{Principles of environmental protection law in the EPA}

\subsection{Principle of usage of the environment}

Art. 4.1. Anyone may commonly use the environment by the power of this act which comprises usage of the environment, without use of any installation, in order to satisfy personal needs and requirements of the household, including leisure and sports, by:1) introducing substances or energy into the environment;2) other than described in item 1 varieties of the common use of waters as recognised by the act of 18 July 2001 Water law (Journal of Laws of 2005, No. 239, item 2019 as amended).

2. Usage of the environment which does not fit the common use may be, if introduced by a separate act, limited by the obligation of obtaining a permit which will determine the scope and conditions of usage, issued by an appropriate environment protection authority.

3. An ordinary usage of the environment is such usage which does not fit the common use, but does not require any permit to be obtained by a suitable act, as well as ordinary usage of water as defined by the act Water law.

Usage of the environment is one of the basic principles referring to the entire environment protection law, excluding those elements of the environment which are governed by separate regulations ${ }^{17}$. Although some authors do not recognise it as a general principle of the environmental law (see footnote 9). As it is stated in article 4 section 1 of the EPA, common use of the environment applies by the force of this act to anyone, so this is the use that cannot be restricted, e.g. by a public authority decision. Common

15 Z. Bukowski, Zrównoważony rozwój..., p. 462. On the sustainable development in other acts referring to the environment protection see: p. 475 and next.

16 D. Pyć, Zasady prawa..., p. 145.

17 I.e. the act water law or the act on forests. See: B. Wierzbowski, B. Rakoczy, Prawo ochrony środowiska. Zagadnienia podstawowe, Warszawa 2010, p. 89. 
use of the environment excludes use of any installation ${ }^{18}$, in order to satisfy personal needs and requirements of the household, e.g. by leisure or sports, which results in introducing substances ${ }^{19}$ or energy into the environment. The environment may be also used by a common usage of water which means to use it for personal, household or farm needs, without deployment of any special technical devices, e.g. for tourism, water sports or fishing (article 34 of the act Water law).

The discussed article 4 features three sorts of environmental usage. Apart from common usage also ordinary usage has been distinguished along with the usage which may be carried out upon a permit. Due to a certain logical imperfection of this regulation it shall be assumed that only two sorts of environmental usage have been distinguished: common and usage which does not fit common use, i.e. exceeds it. The latter divides then into two sorts: ordinary usage which exceeds the framework of common usage but does not require a permit and usage which exceeds the framework of common usage and requires a permit ${ }^{20}$. However the obligation to obtain a permit has to be always grounded by a certain provision of law. If that happens, usage without a proper permit will be punished, e.g. by a penalty fee.

Finally, some words have to be devoted to article 3 section 20 of the EPA which features a category of entities using the environment, which includes: a) entrepreneurs defined by article 4 of the Act on Economic Freedom of 2 July 2004, as well as farmers who deal with cultivations, breeding, gardening, vegetable growing, forestry and inland fishing, as well as persons who run an individual medical practice, b) entities not being entrepreneurs defined by article 4 of the Act on Economic Freedom of 2 July 2004, c) natural persons not being entities defined in letter a) which use the environment in the extent which requires a permit. Hence any natural person who does

18 According to article 3 section 6 of the EPA, installation means a) stationary technical device, b) set of stationary technical devices technologically related, legally owned or possessed by the same entity and located within the same works, c) buildings which are not technical devices or their sets, which exploitation bay result in emission.

19 According to article 3 section 36 of the EPA, substances are chemical elements and their compounds, mixtures or solutions existing in the environment or created by human activity.

20 J. Boć, K. Nowacki, E. Samborska-Boć, Ochrona..., p. 134. It is worth of mentioning that the act Water law features three sorts of water usage: common, ordinary and special. (Section II of the act Water law). This means that the acts, unfortunately, do not operate with the same terms referring to similar or comparable activities. 
not run any business activity (is not recognised as an entrepreneur) and uses the environment in a common way or in a way exceeding the common use, which however does not require any permit, is not recognised as an entity using the environment ${ }^{21}$.

\subsection{Principle of integrity, planning principle}

Art. 5. Preservation of one or more natural elements shall be carried out with respect to preservation of remaining elements.

It seems that the principle of integrity, also known as the principle of integrated protection of the environment ${ }^{22}$, does not require further comments. The environment has to be protected as an integrated system of related elements which influence the other. The environment protection cannot be ruled by good of only one element if this means worsening of other elements. That requires international cooperation and joining efforts of all countries to preserve the Earth ${ }^{23}$.

As previously mentioned, apart from the EPA there are numerous other acts referring to environmental protection, i.e. the act Hunting law or the act on forests. It shall be pointed out that the protection obligation does not only refer to users of the environment but also to the authority which shall make efforts aimed at preserving the environment as a whole ${ }^{24}$, regardless of protection of its single elements.

Poland's membership in the EU has also changed the view on the environmental protection. Previously issued environmental permits covered only certain elements of the environment, e.g. noise emission. Integrated permit featured in Section 4, articles 201-219 of the EPA is the legal instrument which introduces the principle of integrity. It refers to installations which, due to their type and range of operation, may cause

B. Wierzbowski, B. Rakoczy, Prawo ochrony środowiska..., p. 91.

22 P. Korzeniowski notices that the principle of integrity is also a part of other principles i.e. the principle of integrated protection of the environment, the superiority principle or the sustained development principle. See: P. Korzeniowski, Zasady prawne ochrony środowiska, Eódź 2010, p. 335.

23 D. Pyć, Zasady prawa..., p. 130 and next.

24 B. Wierzbowski, B. Rakoczy, Prawo ochrony środowiska..., p. 91. 
severe pollution of the environment or its elements ${ }^{25}$. The regulation of the Minister of the Environment of 2002 lists types of the installations concerned ${ }^{26}$.

At this point also the planning principle, featured in article 8 of the EPA, deserves some comment: Policies, strategies, plans or programmes referring in particular to the industry, power industry, transport, telecommunication, water management, waste management, spatial planning, forestry, farming, fishing, tourism and exploitation of the ground shall comply with the environment protection principles and the sustainable development principle.

While making plans no enterprise protection of the environment, recognised as a gathering of certain natural elements, can be ignored. The above mentioned principle can be understood in a broad and narrow sense. The first one will comprise all possible plans or strategies relating to any procedure which is related to environmental protection. The latter shall mean that all actions aimed at protection of the environment shall be taken in a planned and systematized manner ${ }^{27}$.

In Poland environmental protection programmes are designed at the level of a state and self-government. In the first case this is the ecological policy of the state, in the second - respectively the voivodeship, district and local environmental protection programmes.

\subsection{Prevention principle and precautionary principle}

Art. 6. 1. Who undertakes activity which may be harmful for the environment is obliged to prevent such a harmful impact. 2. Who undertakes activity which negative impact has not been yet fully recognised is obliged, guided by precaution, undertake all necessary preventive measures.

Under the previous act on protection of the environment, the preventive approach towards various undertakings which may cause damages to the environment have been only briefly covered by article 2 section 1 point

\footnotetext{
25 See eg. J. Szuma, K. Szuma, Integrated permits to operate waste management installation in the Polish Environmental Protection Act, Polish Yearbook of Environmental Law, 2011, p. 133-151.

26 Regulation of the Minister of the Environment of 26 July 2002 on types of installations which may result in a serious pollution of the environment or its elements (Journal of Laws of 2002, No. 122, item 1055 as amended).

27 B. Wierzbowski, B. Rakoczy, Prawo ochrony środowiska..., p. 97.
} 
2 which says: 'protection [of the environment] means in particular [...] counterfighting or prevention against harmful influences on the environment which may result in its deterioration, pollution, change of physical characteristics or character of natural elements'. Only the currently in force act enforces a preventive outlook on all actions that have or may have an impact on the environment ${ }^{28}$. Prevention principle and precautionary principle $^{29}$ are well known in the international environmental protection law, hence there and in the EU law the sources and more precise thoughts concerning both principles shall be sought.

The idea behind the environmental protection law is not only restoration of the environment, but foremost prevention against its infringement. As D. Pyć notices, preventive actions are the most effective methods of reaching environmental objectives not only in the international dimension, but also in regional and domestic scale ${ }^{30}$. Hence the weight of both principles is incommensurable and their formulating and execution proves future and intergenerational thinking ${ }^{31}$. An interesting philosophical problem may be seen here, if care of future generations may justify limitations imposed on current ones ${ }^{32}$ ?

It is significant that the scope of addressees of both principles if very wide, since it refers to anyone and the premise of application of both principles is a potentially harmful impact on the environment. That means that the above principles apply to anyone who undertakes actions that may have influence on the environment ${ }^{33}$. Moreover, it is worth to recall article 68 section 4 of the Constitution of Poland here which says: 'Public authorities are obliged to [...] prevent results of the environment degradation which are negative to health'. This regulation extends the scope of entities covered

28 J. Boć, K. Nowacki, E. Samborska-Boć, Ochrona..., p. 135.

29 M. Górski distinguishes prevention principle and precautionary rule. See: M. Górski, Zasada prewencji w prawie ochrony środowiska, "Studia Prawno-Ekonomiczne", band LII 1995 , p. 88 and next.

30 D. Pyć, Zasady prawa..., p. 132-133.

31 M. Pchałek, Zasada przezorności i prewencji, [in:] Europa urzędników, edited by Z. Brodecki, Warszawa 2009, p. 240.

32 A. Erechemla, Oceny oddziatywania na środowisko, jako przyktad realizacji zasady prewencji we wspólnotowym prawie ochrony środowiska, "Studia Europejskie", no. 1/ 2007, p. 117.

33 E. Iwanek-Chachaj, Zasada prewencji i przezorności w prawie ochrony środowiska, “Studia Iuridica Lublinensia”, no. 11/ 2008, p. 140. 
by the obligation stated in article 6 of the EPA, since it also includes public authorities as addressees of the mentioned obligation.

Though both principles have been embraced by one article of the EPA and are commented jointly in literature and their idea is similar, there are some distinctions between them. Prevention means action which aims at avoidance of a negative outcome. The obligation raising from precaution comes into being earlier, since upon planning of impact on the environment it has to be taken into account that at present a certain action does not have to be harmful for the environment, however in the future its negative impact may be revealed. This stands for precaution, which is ability to foresee outcomes which are not known at present. Since prevention means action which shall counterfight any known, negative effects, in case of precaution the goal is to take into consideration negative scenarios which are not yet known or even suspected to produce undesirable effects.

The presented manner of thinking, which proves that the state authority cares for the environment by pushing everyone to prevent its damage, influenced creating of the environmental impact assessment. This instrument, developed in the EU law, was introduced into the Polish law system by the act of 3 October 2008 on the release of information about the environment and its protection, society participation in the environmental protection and environmental impact assessment ${ }^{34}$. By its means any planned enterprise has to be assessed against its environmental impact prior construction. It shall be regarded as an obligatory instrument, hence it supports both presented principles, since during projecting of undertakings perspective and future thinking of the environment cannot be omitted. Environmental impact assessment can be linked with best available techniques (BAT) introduced by article 3 section 10 of the $\mathrm{EPA}^{35}$. The regulations here put an obligation to resort to the best and currently available techniques which

34 Journal of Laws of 2008, No. 199, item 1227 with amendments.

35 By this regulation, best available practices are the most effective and advanced level of technology development and methods of a certain activity, used as a basis for determining the highest emission volumes, which are designed for elimination of emission or, if it is not practically possible, limitation of emission and its impact on the entire environment, whereas: a) 'technique' means both a technology being applied and the way a certain installation is projected, carried out, used or liquidated, b) 'available techniques' means techniques of such advanced stage which enables their practical application in a certain branch of industry, considering economic and technical conditions compared to investment costs and benefits for the environment, which are available to the entity who conducts this activity, c) 'best 
help eliminating or at least limiting emissions ${ }^{36}$. Further details which extend the scope of both principles are available in the act of 13 April 2007 on counterfighting damages in the environment and its restoration ${ }^{37}$.

\section{4. 'Polluter pays’ principle}

Art. 7. 1. Who causes pollution of the environment, bears the costs of its restoration.2. Who may cause pollution of the environment, bears the costs of counterfighting against this pollution.

First it shall be recalled that mentioned above article 86 of the Constitution of Poland imposes the obligation to take care of the environment and take responsibility for its deterioration on anyone, whereas the rules of this responsibility have been set out in the act of 13 April 2007 on counterfighting damages in the environment and its restoration. Article 7 of the EPA, which expresses the ,polluter pays' principle refers to financial responsibility of the polluter for caused or even potential pollution. Pollution here is understood as emission which may be harmful for human health or the environment, may cause damage to material goods, may worsen aesthetic value of the environment or may collide with others, justified ways of use of the environment ${ }^{38}$. It is worth of noticing that pollution of the environment as such has not been prohibited, since the civilization could not exist without affecting, including negative impact, the environment ${ }^{39}$.

Article 7 section 1 includes the compensation aspect, since section 2 emphasises the preventive side of the principle concerned ${ }^{40}$. The compensation aspect comes into play when a damage to the environment, its pollution is caused. The polluter has to bear the costs of its restoration. Damage is a term originating from civil law and invokes compensation.

technique' means the most effective technique in achieving the high general level of the entire environment protection.

36 E. Iwanek-Chachaj, Zasada prewencji i przezornosici..., p. 141.

37 Journal of Laws of 2007, No. 75, item 493 with amendments.

38 Article 3 section 49 of the EPA.

39 A. Lipiński, Z problematyki zasady „zanieczyszczajacy ptaci” [in:] Prawo ochrony srodowiska $i$ prawo karne. Ksiega jubileuszowa z okazji 40-lecia pracy naukowej Profesora Wojciecha Radeckiego edited by H. Lisicka, Wrocław 2008, p. 145.

40 K.M. Klenowska, Zasada zanieczyszczajacy ptaci, [in:] Leksykon ochrony środowiska, edited by J. Ciechanowicz-McLean, Warszawa 2009, p. 397. 
However damage to the environment is defined as a negative, measurable change of the state or functions of natural elements valued against their initial state, caused directly or indirectly by the activity of an entity who uses the environment ${ }^{41}$. According to article $7 \mathrm{a}$ of the EPA the regulations of the act on counterfighting damages in the environment and its restoration shall be applied to damages to the environment. It should be noticed here that that the polluter is not obliged to restore the environment to the previous state but to bear costs of restoration. It is justified by the fact that rarely the environment can be reverted to its state prior pollution, since damages made are often irrevocable. What is more, the term of costs of restoration is wider than the scope of compensation according to the Civil Code ${ }^{42}$.

The polluter is obliged to pay for caused pollution. A. Lipiński, however, is convinced that this principle does not seem to be sound and solid in case restoration of the environment is not possible, i.e. because the polluter is unknown or bankrupt. The problem of restoration paid from public financial resources arises then ${ }^{43}$. J. Boć notices that in case the polluter lacks financial resources, participation of other entities has to be considered. The state treasury or self-government may be billed with the costs. Hence application of this principle is not always possible ${ }^{44}$.

The 'polluter pays' principle can be linked with previously commented article 6 section 1 of the EPA, namely the prevention principle, since article 7 section 2 of the EPA emphasises a preventive approach of this principle, since everyone who potentially may pollute the environment has to bear costs of prevention against such a pollution. So bearing costs is not determined actually by occurrence of a pollution - only possibility is needed here.

The 'polluter pays' principle is supported by economic instruments such as charges and fees. It is also strictly connected with civil (articles 322-328 of the EPA) and management (articles 362-375 of the EPA) responsibility.

41 Article 6 section 11 the act on counterfighting damages in the environment and its restoration.

42 B. Wierzbowski, B. Rakoczy, Prawo ochrony środowiska..., p. 95.

43 A. Lipiński, Z problematyki zasady..., p. 151.

44 J. Boć, Zasady ogólne w ustawie..., p. 80. 


\section{5. '0bligation of usage of reference methodology' principle}

Art. 12. 1. Entities using the environment and public authorities are obliged to use reference methodology if such methodology has been set by the acts of law. 2. If act of law imposes the obligation of usage of reference methodology, usage of another methodology is allowed, if: 1) it allows obtaining more precise results and its application can be justified by meteorological occurrences, mechanisms of physics and chemical processes which substances and energies undergo - in case of substances or energy spreading modelling methodology; 2) full equivalence of results has been proved - in case of other methodology.

'Reference methodology' means a method of measurements or research defined by the act of law, which may include in particular method of samples collection, method of data interpretation, as well as substances or energy spreading modelling methodology. Reference methodology is set out in relevant regulations i.e. the regulation of the Minister of the Environment on evaluation of substances level in the air, being detailed regulations to article 90 section 3 of the EPA or the regulation of the Minister of the Environment on soil and ground quality standards, being detailed regulations to article 105 of the EPA. If the act of law sets out methodology, then entities using the environment are obliged to apply it. Usage of another methodology is allowed under two conditions. Firstly, whenever it allows obtaining more precise results and its application can be justified by i.e. meteorological occurrences. Secondly, if one can prove their full equivalence comparing to methodology set out by the act of law.

\section{Principles of environmental protection law in other acts of law - right to environmental information principle and principle of society's right to participation in proceedings on decisions referring to environmental protection}

According to article 74 section 3 of the Constitution of Poland, anyone has the right to information on the environment. More precise regulation of this matter can be found in articles 8-28 of the Act of 3 October 2008 
on Release of Information about the Environment and its Protection, Society Participation in the Environment Protection and Environmental Impact Assessment. Its article 4 says that everyone has the right to information on the environmental conditions set out by this act. Simultaneously, public authorities are obliged to release such information which is available to them or directed to them. These include e.g. information on condition of certain elements of the environment like air, climate, plants and animals. They may also refer to reports on execution of environmental protection law regulations. The information can be released upon a motion which shall be answered immediately, not later however than after one month. There are however cases in which a public authority will refuse to release information (article 16 section 1), i.e. if the release would violate regulations concerning protection of personal data or if the release would cause danger to the environment or ecological safety. In some cases public authority may refuse to release information, e.g. if this would require sharing documents or data which are being processed by the authority (article 17 section 1 ). The supplementary way of obtaining information on the environment are public registers (articles 21-25), including the Public Information Bulletin ${ }^{45}$. As a rule the information is given for free, but some fees i.e. for copying materials may apply.

The act on release of environmental information and its protection sets out the rules of society participation in the environment protection in articles 29-45. Anyone has the right to take part in a proceeding which requires the society participation on the conditions set out by this act (article 5) and anyone has the right to fill remarks and motions in the proceeding which requires the society participation (article 29). Prior to issuing a decision in a proceeding which requires society participation, public authority publishes information on proceeding initiation, availability of documentation, possibility of filling remarks and motions, and - after the proceeding is finished - the authority publishes the information on issuing the decision and publishes the decision itself. Ecological organisations, which are social organisations focused on environmental protection (article 3 section 1 point 10), may take part in the proceeding (article 44).

It is worth mentioning that both of the above described forms of the constitutional right to information principle are quite new in the Polish

45 http://www.bip.gov.pl/ 
Katarzyna Lew-Gliniecka

environmental protection law and have been introduced under the influence of the EU law.

\section{Summary}

The aim of this study was to present Polish environmental protection law principles in general and correlations between them. Most of the principles are influenced by international law, in particularly the EU law. Each branch of law has its own general principles. Since the environmental protection law is not commonly recognised as a standalone branch of law, there is a problem with determining its core general principles. Another thing is that undoubtedly certain principles of environmental protection law can be distinguished, however, setting their hierarchy may be found disputable, as well as answering the question if they can be defined as general environmental law principles or only local principles which do not go further than the act on environmental protection. Finally, there is an issue of distinguishing certain principles and their proper presentation.

Numerous disputes concerning principles of environmental law have been presented which show that legal present of the latter has been perceived, which is also confirmed by literature. Hence, notwithstanding the status of principles and doubts or disputes around them they make the whole legal system more coherent in its basic aim which is securing clean environment and its restoration in case of pollution. 